\title{
MRS BULLETIN Seeks Contributions
}

\author{
Technical Reviews, News, Opinions
}

The Editorial Board under the direction of Elton Kaufmann is seeking contributions such as technical reviews, news items and activities of interest to the membership.

The BULLETIN is growing rapidly, but still needs assistance from the materials community to provide more thorough and responsible reports. MRS members and other readers are encouraged to contribute items in any of the following areas.

\section{Technical Reviews}

Short technical reviews written in a clear expository manner with abbreviated reference citations and uncomplicated cameraready illustrations are sought. Articles should be a maximum of three published BULLETIN pages $(4,500$ words or equivalent). Contributions by professionals who can bring perspective to a field of endeavor while describing research of current interest are particularly welcome

\section{Guest Editorials}

One-page editorials or commentaries on issues of current interest are invited. Voluntary contributions and recommendations of other potential contributors are sought.

\section{Obituaries}

The passing of a colleague should be noted in the BULLETIN in a timely manner by inclusion of an obituary prepared by colleagues whocan highlight the career history and contributions of the deceased.

\section{Book Reviews}

Persons interested in providing a thought- ful review of a newly published volume on materials science and technology may obtain a list of books made available to the Editorial Board by major science publishers. Reviewers may also suggest other titles they wish to critique.

\section{Personal Notes}

Job changes, awards, promotions, major contract awards, and similar news items of interest to the readership are invited. Members are encouraged to cont ribute this information (along with the name and telephone number of a person who can be contacted for further information on the story). Readers are also encouraged to tell their organization's public relations department of the BULLETIN's desire to receive news releases from them on similar news items. Photographs related to the stories will also be considered for publication.

\section{Situations Wanted}

The BULLETIN will publish "Situations Wanted" announcements free for MRS members. Experience indicates that use of this confidential forum is an effective means of reaching prospective employers. Messages are to be no more than 75 words and will be published in the earliest available issue of the BULLETIN. Organizations may purchase advertising space for "Positions Available" notices.

\section{Letters to the Editor}

The BULLETIN will print signed letters from readers on topics of interest. The Editor reserves the right to edit submissions for style and space limitations, but will endeavor to preserve the writer's words and intent as far as possible.

\section{Society News}

The BULLETIN is still the primary vehicle for reporting news and announcements of MRS activities on the local, national, and international level. Local Sections, Student Chapters, and Committees will publish reports on their activities on a regular basis

\section{How to Submit Items to the BULLETIN \\ Submissions and questions regarding tech- nical reviews, guest editorials, obituaries, letters to the editor, and book reviews should be sent to Elton Kaufmann, Law- rence Livermore National Laboratory, P.O. Box 808, L-370, Livermore, CA 94550; telephone (415) 423-2640 or to any of the Editorial Board members listed on page 2 of the BULLETIN.}

Articles on and requests for additional information concerning personal notes, situations wanted, and Society news should be sent to Gail Oare, Editor, MRS Bulletin, Materials Research Society, 9800 McKnight Road, Suite 327, Pittsburgh, PA 15237; telephone (412) 367-3036.

Other suggestions and ideas for coverage in the BULLETIN are invited, as the BULLETIN is a service to you. Contact any Editorial Board member, Society Officer, Councillor, Committee member, or MRS staff member to voice your ideas.

MRIS

\section{MRS BULLETIN Covers the Significant Developments and Trends in Materials Research}

To ensure that interesting developments at your institution are brought to the attention of your colleagues around the world, ask your public relations or public affairs department to send information for inclusion in the BULLETIN to:

Gail Oare, Editor

MRS BULLETIN

9800 McKnight Road, Suite 327

Pittsburgh, PA 15237

telephone (412) 367-3036 